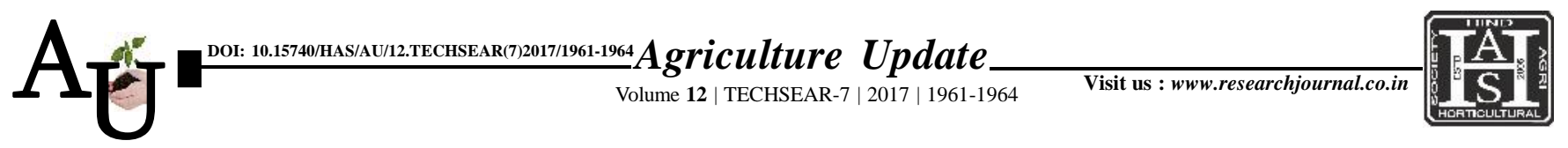

\title{
Research Article: Genetic parameters for yield improvement in sesame
}

Article Chronicle:

Received :

19.07.2017;

Accepted :

03.08.2017

KeY Words:

Genetic variability,

Heritability, PCV, GCV,

Sesame
Author for correspondence :

\section{PADMAJA}

Regional Agricultural

Research Station,

Polasa, JAGTIAL

(TELANGANA) INDIA

Email : suhanigpb@

gmail.com

See end of the article for

authors' affiliations

\section{PADMAJA, T. SHOBHARANI, T. KIRAN BABU, P. MADHUKAR RAO, M. VENKATAIAH, D. KALPANA, PRAGNA AND S. LAXMAN}

SUMMARY : This study was carried out using seventeen advanced varietal lines during Kharif 2016 at Regional Agricultural Research Station, Polasa, Jagtial, Telangana state. The evaluation of phenotypic and genotypic co-efficient of variation, heritability and genetic advance as per cent of mean were calculated for various agronomic characters. High values for phenotypic co-efficient of variation (PCV) and genotypic co-efficient of variation (GCV) was recorded for seed yield per hectare, number of capsules per plant and number of branches per plant and hence improvement through selection could be possible. High heritability combined with high genetic advance was recorded for yield per hectare followed by number of capsules per plant, days to $50 \%$ flowering. While moderate heritability coupled with high genetic advance as per cent of mean for number of branches per plant indicating the influence of additive gene action, as such simple selection would likely to be effective for improvement of these traits. Indicating that selection of these characters would be effective for further breeding purpose.

How to cite this article : Padmaja, D., Shobharani, T., Babu, T. Kiran, Rao, P. Madhukar, Venkataiah, M., Kalpana, D., Pragna and Laxman, S. (2017). Genetic parameters for yield improvement in sesame. Agric. Update, 12(TECHSEAR-7) : 1961-1964; DOI: 10.15740/HAS/AU/12.TECHSEAR(7)2017/1961-1964. 